\title{
PIIISGUC.ORG
}

"iş, GÜÇ" ENDÜSTRi iLişKILERI VE INSAN KAYNAKLARI DERGISi

"IS, GUC" INDUSTRIAL RELATIONS AND HUMAN RESOURCES JOURNAL

\section{The Effects Of Gender Inequalities In The Labor Market And The Social Security System On Women's Social Inclusion In Turkey}

\author{
Res.Ass.Osman TEZGEL
}

Dr., Ankara University, Faculty of Political Science, Labor Economics and Industrial Relations

\section{Şenay GÖKBAYRAK}

Associate Prof. Ankara University Faculty of Political Science, Labor Economics and Industrial Relations

Ekim/October 2013, Cilt/Vol: 15, Say1/Num: 4, Page: 39-59

ISSN: 1303-2860, DOI: 10.4026/1303-2860.2013.0236.x

Makalenin on-line kopyasına erişmek için / To reach the on-line copy of article: http://www.isguc.org/index.php?p=article\&id=539\&cilt=15\&sayi $=4 \& y i l=2013$

Makale İçin İletişim/Correspondence to:

Doç.Dr.Şenay GÖKBAYRAK / Email: senay.gokbayrak@gmail.com 


\title{
FIIISGUCOPG 0200020213 \\ "İş,Güç" Endüstri ilişkileri ve İnsan Kaynakları Dergisi "Işs,Güç" Industrial Relations and Human Resources Journal
}

\author{
Ekim/October 2013, Cilt/Vol: 15, Sayı/Num: 4, \\ Sayfa/Page: 39-59, DOI: 10.4026/1303-2860.2013.0236.x
}

"İş,Güç" Endüstri İlişkileri ve İnsan Kaynakları Dergisi, yılda dört kez yayınlanan hakemli, bilimsel elektronik dergidir. Çalışma hayatına ilişkin makalelere yer verilen derginin temel amact; belirlenen alanda akademik gelişime ve paylaşıma katkıda bulunmaktır.

"İş,Güç" Endüstri İlişkileri ve İnsan Kaynakları Dergisi'nde, 'Türkçe' ve 'İngilizce' olarak iki dilde makale yayınlanmaktadır. "İş,Güç" Endüstri İlişkileri ve İnsan Kaynakları Dergisi, ulusal ve uluslararası birçok indekste taranmaktadır. (Cabell's Directories, Ebsco Socindex, Index Islamicus, Index Copernicus International, Worldwide Political Science Abstracts, Sociological Abstract, Ulakbim Sosyal Bilimler Veritabanı, ASOS Index)

Editörler Kurulu / Editorial Board Aşkın Keser (Uludă̆ University) K.Ahmet Sevimli (Uludă̆ University) Şenol Baştürk (Uludağ University)

\section{Editör / Editor in Chief}

Şenol Baştürk (Uludăg University)

\section{Uygulama / Design}

Yusuf Budak (Kocaeli University)

Tarandığı Indeksler / Indexes ASOS INDEX

CABELL'S DIRECTORIES EBSCO SOCINDEX Index ISLAMICUS Index COPERNICUS Int.

Sociological Abstract

ULAKBİM Sosyal Bilimler

Veritanı

Worldwide Political Science

Abstracts

\author{
Yayın Kurulu / Editorial Board \\ Dr.Şenol Baştürk (Uludă̆ University) \\ Yrd.Doç.Dr.Zerrin Fırat (Uludă̆ University) \\ Doç.Dr.Aşkın Keser (Uludă̆ University) \\ Prof.Dr.Ahmet Selamoğlu (Kocaeli University) \\ Yrd.Doç.Dr.Ahmet Sevimli (Uludağ University) \\ Doç.Dr.Abdulkadir Şenkal (Kocaeli University) \\ Doç.Dr.Gözde Yılmaz (Marmara University) \\ Yrd.Doç.Dr.Memet Zencirkıran (Uludağ University)
}

Uluslararası Danışma Kurulu / International Advisory Board
Prof.Dr.Ronald Burke (York University - Kanada)
Assoc.Prof.Dr.Glenn Dawes (James Cook University - Avustralya)
Prof.Dr.Jan Dul (Erasmus University - Hollanda)
Prof.Dr.Alev Efendioğlu (University of San Francisco - ABD)
Prof.Dr.Adrian Furnham (University College London - İngiltere)
Prof.Dr.Alan Geare (University of Otago - Yeni Zellanda)
Assoc. Prof. Dr. Diana Lipinskiene (Kaunos University - Litvanya)
Prof.Dr.George Manning (Northern Kentucky University - ABD)
Prof.Dr.Mustafa Özbilgin (Brunel University - UK)
Assoc. Prof. Owen Stanley (James Cook University - Avustralya)
Prof.Dr.Işık Urla Zeytinoğlu (McMaster University - Kanada)

Ulusal Danışma Kurulu / National Advisory Board

Prof.Dr.Yusuf Alper (Uludağ University)

Prof.Dr.Veysel Bozkurt (Ístanbul University)

Prof.Dr.Toker Dereli (Işık University)

Prof.Dr.Nihat Erdoğmuş (İstanbul Şehir University)

Prof.Dr.Ahmet Makal (Ankara University)

Prof.Dr.Süleyman Özdemir (İstanbul University)

Prof.Dr.Ahmet Selamoğlu (Kocaeli University)

Prof.Dr.Nadir Suğur (Anadolu University)

Prof.Dr.Nursel Telman (Maltepe University)

Prof.Dr.Cavide Uyargil (Istanbul University)

Prof.Dr.Engin Yildırım (Anayasa Mahkemesi)

Doç.Dr.Arzu Wasti (Sabancı University)

Dergide yayınlanan yazılardaki görüşler ve bu konudaki sorumluluk yazarlarına aittir.

Yayınlanan eserlerde yer alan tüm içerik kaynak gösterilmeden kullanılamaz.

All the opinions written in articles are under responsibilities of the authors.

The published contents in the articles cannot be used without being cited. 


\title{
The Effects Of Gender Inequalities In The Labor Market And The Social Security System On Women's Social Inclusion In Turkey ${ }^{1}$
}

\author{
Res.Ass.Osman TEZGEL \\ Dr., Ankara University, Faculty of Political Science, Labor Economics and Industrial \\ Relations
}

\section{Şenay GÖKBAYRAK}

Associate Prof. Ankara University Faculty of Political Science, Labor Economics and Industrial Relations

\begin{abstract}
The main aim of this study is to explore the causality between the disadvantaged status of women in the labor market and the social security system in Turkey and the exclusion/inclusion phenomenon. Within this context, the conditions of women employment in Turkey, labor force participation rates, the features of jobs in which women concentrate and their working status are analyzed based on the existing dual labor market structure (formal-informal and rural-urban). This study indicates that the transformation of the labor market and the social security system increase the gender inequalities. Flexibilization and conservatism process of the labor market obstruct to eliminate the gender inequalities within the social security system. Therefore, it is essential to implement women friendly employment and social security policies.
\end{abstract}

Key Words: Women employment, social security, social inclusion, social exclusion, welfare regime.

\section{Özet}

Bu çalışmanın temel amacı, Türkiye'de kadınların işgücü piyasası ve sosyal güvenlik sistemindeki dezavantajlı konumları ile sosyal içermeleri/dışlanmaları arasındaki nedensellik ilişkilerini açıklamaktır. Bu çerçevede çalışmada, Türkiye'de kadın istihdamın durumu, işgücü piyasalarına katılım oranları, kadınların yoğunlaş̧ıkları işlerin özellikleri ve kadınların çalışma statüleri, işgücü piyasalarının ikili yapısl (formel-enformel ve kirsal-kentsel) temel alınarak analiz edilmiştir. Çalışma, işgücü piyasalarında ve sosyal güvenlik sistemlerinde yaşanan dönüşümün toplumsal cinsiyet eşitsizliklerini arttırdı̆̆ını göstermektedir. İsgücü piyasalarında yaşanan esnekleşme ve muhafazakârlaşma süreci, sosyal güvenlik sistemindeki toplumsal cinsiyet eşitsizliklerini yok etmeyi zorlaştırmaktadır. Bu nedenle, kadın dostu istihdam ve sosyal güvenlik politikalarının uygulanması önem taşımaktadır.

Anahtar Kelimeler: Kadın istihdamı, sosyal güvenlik, sosyal içerme, sosyal dışlanma, refah rejimi.

\footnotetext{
${ }^{1}$ This paper is the extended version of the oral presentation submitted in the "Joint World Conference on Social Work and Social Development: Action and Impact" held in Stockholm, Sweden on 09.07.2012
} 
"iş, GÜç" Endüstri iliş̧kileri ve İnsan Kaynakları Dergisi

"IS, GUC" Industrial Relations and Human Resources Journal
October/Ekim 2013 - Cilt/Vol: 15 - Sayı/Num: 04 Sayfa/Page: 39-59, DOI: 10.4026/1303-2860.2013.0236.x

\section{Introduction}

In a broad sense the social security systems which aim to protect people from the future uncertainties/risks exist as different systems emerged according to historical, social and political dynamics of the countries. The social security systems are shaped by different features of the welfare regime which is determined by different forms of welfare creation and distribution. The transformation process of the welfare regimes appeared as a result of variable circumstances shows a pathdependency character and the social security systems try to realize the transformation by keeping their existing features. The welfare systems differentiate regarding the main actors in the process of welfare creation, the level of protection against market risks and segmented structure within the society. In terms of ensuring social justice and equality the performance of the system is also determined by the features of the welfare regime. The systems are decisive not only among social classes but also in reducing or reproducing gender inequalities. Studies which aim to explain the relationship between the welfare regime and gender basically focus on this point, as well.

The social security systems developed in the post-World War II period are based on full-time regular male workers. In this system the welfare programs protect primarily male workers and the majority of women gain access to the system as being dependent on men. Although women contribute to the creation of welfare significantly, they become second-class citizens. The dependency status of women on gaining access to the welfare program entails that their current and future security is determined upon men (fathers or husbands). The main reason of this dependent and invisible status of women in a welfare state is the care responsibility encumbered to women within the framework of the gender based division of labor. Women are prevented to gain access to the labor market and to be permanent in it because the household reproduction activities are described as their responsibility. Women who are not able to participate in the labor market regularly and consistently are excluded from the social insurance programs which are based on employment and regular contributions or access only the social benefit programs which are not based on contributions. In order to solve the problem of women gaining access to the social security system a consensus on ensuring their access to the labor market has been emerged. However, ensuring the access to the labor market is practical yet not enough for women to gain the full citizenship in a welfare state. Thus, the status of women in the labor market is the main decisive factor in gaining access to the social security system.

This study aims to evaluate the effects of the status of women on their inclusion in the labor market and the social security system within the framework of the characteristics of the welfare regime in Turkey where a social security model based on working prevails. By having such a model, the causality between the disadvantaged status of women in the social security system and the exclusion/inclusion phenomenon becomes much more important. Within this respect, in the first part of this study the main characteristics of the Turkish welfare regime are introduced. In the second part, the labor force participation rates for women are detailed within the framework of the main characteristics of the Turkish labor market. Furthermore in this part, the decisive factors of the low labor force participation rates for women are discussed. In the third part, within the scope of the characteristics of the Turkish welfare regime, the status of women in the Turkish social security system and the obstacles in gaining access to the system are analyzed. Finally, in the last part of this study some suggestions concerning the social inclusion of women are offered. 


\section{I- The Main Characteristics of the Welfare Regime in Turkey}

A welfare regime of a country is identified by how the welfare services needed by individuals are shared with these three institutions: The public, the households and the market (Özar and Çakar, 2012:1). The institutionalization of welfare services in countries is determined by the concept of welfare regimes. This concept is significant by forming the public social policy reforms and how the citizenship regimes represent a cooperation model between the citizens in a country. A classification put up by EspingAndersen shows that there are three main welfare regimes in developed countries: i. The Scandinavian model, which the most developed welfare regimes appear, ii. The Continental European model which indicates the countries that have middle leveled welfare regime, and lastly iii. The Liberal model indicates the countries which have residual welfare regime (Esping - Andersen, 1990; Bussemaker and Kersbergen, 1994: 12; Özdemir, 2005: 240). Apart from this classification, a specific welfare regime can be defined for Southern European countries. According to Ferrera (1996) the Southern European countries are defined in a separate welfare regime category. The main factors that distinguish the Southern European welfare regime from the Continental European welfare regime are the segmented structure of social protection subject to participate in the labor market and the clientalistic welfare perception.

Another distinction between the welfare systems is shown up by financing the social security and three models are expressed within these terms. i. The Bismarckian Model, which aims at providing social welfare with the help of contributions that every worker or their employers pay. ii. The Beveridge Model which carries out a common insurance system that includes a whole population of a country. iii. The Hybrid Model is the mixture of Bismarckian and the Beveridge models (Delsen, Van Gestel and Pennings; 2000:1-5 Özdemir, 2005: 236).
The above mentioned classification is the classification between welfare systems as their approaches to financing the social security systems. The Turkish Social Security System basically provides social protection only those who take place in regular/formal employment. Thus, Turkish welfare system can be defined as the Bismarckian Welfare Model. However, the low levels of formal employment in the total employment rate causes a vast majority of the population to benefit from the social security system as being dependent on a family member (generally father/husband) who takes place in regular/formal employment. The social protection as a part of the social security system primarily includes health and retirement assurance provided to the head of household and in Turkey frequently the rest of the family members are dependent on the male head of household in terms of social security (Gökbayrak, 2009:69). This especially applies to women who are not able to enter into the labor market or are not able to be permanent in the labor market because of the gender roles. One of the family members who has a job in the formal sector and thus participates in the social security system enables the rest of the family to enter into the system. Therefore the other members of the family do not care about working in the formal sector especially under circumstances where the creation of employment in this sector is low. This dual structure brings the Turkish welfare regime closer to the Southern European welfare regime (Ferrera, 1996).

Another factor that creates the segmented welfare regime in Turkey is the sectorial distribution of employment. According to the statistics of Turkish Statistical Institute in April 2013, "of those who were employed, $23.6 \%$ were employed in agriculture, $19.6 \%$ were employed in industry, $7 \%$ were employed in construction and $49.9 \%$ were employed in services" (Turkstat, 2013). In 2012, in the developed economies such as England, the \%1.2 part of the total employment located in agriculture. In other developed countries, proportions of the employment in agriculture are \%1.5 in Germany, \% 2.9 in France and $3.7 \%$ in Italy (Eurostat, 2013). The 
employment size in agriculture also identifies the welfare regimes of a country. Over the past ten years the size of the agricultural sector has been narrowed but the extent of this sector still protects its significance in Turkey ${ }^{2}$. The continuous surplus labor in agriculture and the difficulties in including the agricultural workers to the social security system create a rural/urban dualism in gaining access to social security. The coverage of the social security system is quite low in the rural areas and it is almost impossible for the women who work in agriculture to access and remain registered in the social security system.

The Turkish welfare system has a hierarchical, complex and segmented structure as a result of the formal - informal and urban rural distinction of the Turkish labor market. The complex and segmented structure of the Turkish welfare system fundamentally leads families to provide social protection in traditional family solidarity. On the one hand family solidarity transforms women into an important welfare actor who is responsible from the care services because of the gender role; on the other hand it excludes women from the labor markets and thus from the social security system. Hence, social inclusion of women entails to take place in regular employment.

\footnotetext{
${ }^{2}$ Romania as one of the Southern European countries has a similar rate of employment in agriculture. The statistics of 2012 indicates that in Romania 29 $\%$ of the total employment take place in agriculture. Although the proportion of the agriculture in total employment is lower, for instance the employment in agriculture is \% 13 in Greece, $13.7 \%$ in Croatia and $17 \%$ in Macedonia (Eurostat, 2012).
}

\section{II- The Status of Women in the Turkish Labor Market}

\subsection{The structure of the Turkish Labor Market and The Labor Force Participation Rate of Women}

The dual structure of the Turkish labor market and the distinction between urban and rural areas carries importance in the Turkish labor market analyses (Ceylan Ataman, 1999: 93). Although the extent of the agriculture in the sectorial distribution of employment decreases over the years, according to the Turkish Statistical Institute's Household Labor Force Survey Results, 23.6 \% of the work force is still employed in agriculture (Turkstat, 2013). Hence, the excess of the employment rate in agriculture leads the Turkish labor market to be considered among the developing countries. Consequently the Turkish labor market indicators differ between urban and rural areas. Besides, the distinction between urban and rural labor markets reveals a considerable diversity between men and women and between skilled and unskilled labor.

The model of export-oriented industrialization in the post-1980's revealed a decline in the employment and the production in agricultural sector (Toksöz, 2012: 169). The decline in the agricultural sector has caused a considerable amount of migration from rural to urban areas. Combined with the rapid growth of the population, the rural to urban migration has caused the expansion of the informal sector. On the other hand, within the decline in the agricultural employment, the industrial and service sectors were not capable of putting forward productive formal employment sources. Therefore, this structural transformation has caused a considerable growth in income inequalities, informal employment and social exclusion (Sapancalı, 2007: 12).

The other main characteristic of the Turkish labor market is the gender gap in employment and the lower labor force participation rate for women. The main reason 
of the low labor force participation rate for women in Turkey is the sociocultural facts that affect the labor supply and labor demand for women. Although the female employment has increased in the world since 1990's, the labor force participation rate for women has stayed quite low in Turkey. In 2012 the average labor force participation rate of EU countries is \% 50.8; whereas women's labor force participation rate in Turkey is \% 29.5 (ILO, 2012: 96). Despite the high growth rates of Turkish Economy after the 2001 economic crisis, it is emphasized that the economic growth in Turkey does not increase the employment. The declines in employment in absolute terms and in the labor force participation rates of women indicate that the consequence of the economic growth without employment generally affects women (Toksöz, 2007: 18). Therefore, even if they desire, women are not able to enter into the labor market easily. Table- 1 presents the labor force participation rate for both men and women in urban and rural areas.

Table - 1: Labor Force Participation Rates from Urban, Rural and Gender Perspective

\begin{tabular}{|c|c|c|c|c|c|c|c|c|c|}
\hline & \multicolumn{3}{|c|}{ Turkey \% } & \multicolumn{3}{c|}{ Urban \% } & \multicolumn{3}{|c|}{ Rural \% } \\
\hline Years & Total & Men & Women & Total & Men & Women & Total & Men & Women \\
\hline $\mathbf{2 0 0 0}$ & 49.9 & 73.7 & 26.6 & 44.1 & 70.9 & 17.2 & 58.7 & 77.9 & 40.2 \\
\hline $\mathbf{2 0 0 1}$ & 49.8 & 72.9 & 27.1 & 44 & 70.6 & 17.4 & 58.7 & 76.4 & 41.7 \\
\hline $\mathbf{2 0 0 2}$ & 49.6 & 71.6 & 27.9 & 44.4 & 69.8 & 19.1 & 57.6 & 74.5 & 41.4 \\
\hline $\mathbf{2 0 0 3}$ & 48.3 & 70.4 & 26.6 & 43.8 & 68.9 & 18.5 & 55.5 & 72.9 & 39 \\
\hline $\mathbf{2 0 0 4}$ & 46.3 & 70.3 & 23.3 & 43 & 69.1 & 17.7 & 54.4 & 73.3 & 36.7 \\
\hline $\mathbf{2 0 0 5}$ & 46.4 & 70.6 & 23.3 & 44.1 & 70 & 18.7 & 52.1 & 72 & 33.9 \\
\hline $\mathbf{2 0 0 6}$ & 46.3 & 69.9 & 23.6 & 44.2 & 69.3 & 19.5 & 51.2 & 71.3 & 33.1 \\
\hline $\mathbf{2 0 0 7}$ & 46.2 & 69.8 & 23.6 & 44.3 & 69.3 & 19.8 & 50.8 & 71 & 32.5 \\
\hline $\mathbf{2 0 0 8}$ & 46.9 & 70.1 & 24.5 & 45 & 69.5 & 20.8 & 51.4 & 71.6 & 32.9 \\
\hline $\mathbf{2 0 0 9}$ & 47.9 & 70.5 & 26 & 45.8 & 69.9 & 22.3 & 52.7 & 72 & 34.6 \\
\hline $\mathbf{2 0 1 0}$ & 48.8 & 70.8 & 27.6 & 46.8 & 70.4 & 23.7 & 53.5 & 71.6 & 36.3 \\
\hline $\mathbf{2 0 1 1}$ & 49.9 & 71.7 & 28.8 & 47.6 & 71 & 24.8 & 54.9 & 73.3 & 37.5 \\
\hline $\mathbf{2 0 1 2}$ & 50 & 71 & 29.5 & 48.3 & 71 & 26.1 & 53.6 & 71.2 & 36.9 \\
\hline $\mathbf{2 0 1 3}$ & 51.1 & 71.6 & 31.2 & 49.6 & - & - & 54.6 & - & - \\
\hline
\end{tabular}

* Based on April 2013 data (Turkstat; 2013).

Source: (Turkstat, 2012: 78) 
As can be seen from Table - 1, despite a minor increase after 2008, the labor force participation rate for women in Turkey is quite inadequate when compared with the labor force participation rate for men. There is a huge gap between the male and female labor force participation rates. According to April 2013 statistics, the labor force participation rate for men is \%71.6; whereas the labor force participation rate for women is \%31.2. Especially the labor force participation rate for women in urban areas is substantially low. The reason is that the female employment mainly concentrates in agriculture and the migrant female workers from the rural areas are not able to take place in urban formal employment. The decline in agriculture leaded to rural - urban migration after the 1990's and the proportion of the population in rural and urban areas has changed. Although the labor force participation rate for women in the rural areas is relatively high; with the increase of the proportion of urban population the total labor force participation rate for women declines. Nevertheless, the decline in the agricultural sector in Turkey precipitates a significant decrease in the rural labor force participation rate for women (Toksöz, 2007: 19).

Due to the rural - urban migration, in the urban areas the unskilled women labor is excluded from the formal labor markets and concentrates in the informal sector such as cleaning sector, nursing services or carries out piecework as home based workers (Erdut, 2005; Özkaplan, 2008). Frequently, women are employed mostly in informal sector due to the low level of education, the lack of knowledge and skills required by the formal market. Accordingly, women are obliged to work in non-regular, low-paid jobs devoid of social security. Besides, the flexible nature of these jobs enables women to enter into a job quickly and quit whenever desired. These circumstances strengthen the traditional gender roles and provide opportunity for women to adjust the working life with the domestic responsibilities (Kalaycıoğlu and RittersbergerTılıç, 1998).

As can be seen from the Table - 1, there is also a decrease in the labor force participation rate for men both in rural and agricultural sector. Especially at the rural areas the decrease is more distinctive. This can be also explained with the decline of the agricultural sector. But the decrease in the labor force participation rate for men is much lower when it is compared with women. As men are able to take place in different non-agricultural employment in urban areas, female workers mostly are excluded from labor markets and obliged to carry out domestic work (Ecevit, 2009: 7).

Beside the sectorial structure that affects the labor force participation rates of women, education is also one of the main factors that determine the labor force participation rate for women. Table -2 presents the labor force participation rates for men and women regarding the stages of education. 
Table - 2: Labor Force Participation Rates by Gender and Level of Education in Turkey (\%)

\begin{tabular}{|l|c|c|c|c|c|c|}
\hline \multirow{2}{*}{} & \multicolumn{2}{|c|}{1990} & \multicolumn{2}{c|}{2000} & \multicolumn{2}{c|}{2010} \\
\cline { 2 - 7 } & Male & Female & Male & Female & Male & Female \\
\hline Illiterate & 62.3 & 31.6 & 56.7 & 25.2 & 36.8 & 16.3 \\
\hline Literate Without Diploma & 72.2 & 34.8 & 55.8 & 22.2 & 55.2 & 20.4 \\
\hline Primary School Grad. & 87.5 & 34.2 & 81.1 & 24.5 & 75.1 & 25.7 \\
\hline Junior/Vocational High School Grad. & 61.8 & 19.1 & 62.8 & 22.8 & 82.3 & 24.6 \\
\hline High School Grad. & 77.8 & 43.7 & 67.0 & 30.4 & 68.1 & 30.4 \\
\hline Vocational High School Grad. & 81.0 & 51.1 & 79.0 & 42.4 & 81.2 & 39.8 \\
\hline Higher Education or Faculty Grad. & 90.5 & 80.5 & 83.2 & 70.8 & 84.3 & 71.0 \\
\hline
\end{tabular}

Source: Turkstat, 1990 - 2010 (as cited in Günsoy and Özsoy, 2012: 29)

As can be seen from the table the labor force participation rates of women increase with the level of education rises. Education is also correlated with the labor force participation rate for men but the effect of education is more distinctive in the labor force participation rate of women. The higher educated women's labor force participation rate is considerably high but lower educated women's labor force participation rate is quite low. The vast majority of women in Turkey are primary school graduates and the lack of education has an adverse impact on women's labor force participation rates (Dayığlu and Kirdar, 2010: 27).

This fact also reflects the educational gender discrimination between men and women in Turkey. Although the higher levels of education enable women to be employed more easily, even higher educated women remain vulnerable against discriminatory practices in working life, which are not organized from a female perspective. Thus women frequently face difficulties to find a job, to hold on the job and to make progress in the job.

As well as employment, high unemployment rates for men and women are also one of the structural characteristics of the Turkish labor market. Table -3 indicates the unemployment rates for both men and women.

Table - 3: Unemployment Rates for Men and Women

\begin{tabular}{|c|c|c|c|}
\hline \multirow{2}{*}{ Years } & \multicolumn{3}{|c|}{ Unemployment Rate (\%) } \\
\cline { 2 - 4 } & Total & Men & Women \\
\hline 2007 & 10.3 & 10.0 & 11.0 \\
\hline 2008 & 11.0 & 10.7 & 11.6 \\
\hline 2009 & 14.0 & 13.9 & 14.3 \\
\hline 2010 & 11.9 & 11.4 & 13.0 \\
\hline 2011 & 9.8 & 9.2 & 11.3 \\
\hline 2012 & 9.2 & 8.5 & 10.8 \\
\hline
\end{tabular}

Source: (Turkstat, 2012: 81) 
When the unemployment rates examined, it can be seen that the unemployment rates of women are invariably higher than the unemployment rates of man. It can also be seen that there is an increase between the gender gaps in unemployment rates. In 2012 the unemployment rate for men is $8.5 \%$; whereas the unemployment rate for women is $10.8 \%$. Dedeoğlu points out that the actual unemployment rates of women are higher than the ones which given in the statistics. In order to understand the dimensions of women's unemployment, the women who are ready to work but not seeking for a job and the underemployed women who are still seeking for a job even they already have one must together be taken into account. Moreover, some women who take place in agriculture as unpaid family workers can easily be added to the unemployment category and millions of women in urban areas are defined as housewives who are not sorted in the unemployment category (2009: 50). Having significantly low labor force participation rates and high unemployment rates induce women to encounter with poverty. These factors reproduce the dependency of women and consequently women's living status is determined subject to the income of men.

\subsection{Gender Discrimination in the Turkish Labor Market and Conservatism of the Employment Relations}

The phenomenon of strict gender based social roles and conservatism that reproduces these roles influentially the gender discrimination regarding women employment constitutes a grave impediment to women participation in the labor market. The exclusion of women as a result of gender discrimination and conservatism in the labor market can be analyzed from several aspects. Initially, "the gender-based division of labor identifies the form of labor that men and women share and at the same time it refers to the power relations between men and women and reproduces them" (Dedeoğlu, 2000: 150).

In Turkey women employment varies also from urban to rural areas. In rural where the agricultural production is massive, women are employed in the form of unpaid family labor; whereas in urban areas women are faced with various difficulties at participating in the labor market because of the conservative employment relations and although it appears in different levels in urban areas, it can be said that the patriarchal consideration which is against women participation in the labor market tends to increase throughout Turkey (Buğra, 2010: 912). As a result of the gender-based division of labor, the concept of "women" has been degraded to concept of "mother, wife and daughter". The patriarchal system reproduces the mother perception of women and this perception underestimates women in society and working life. The Figure -1 presents the facts why women are not in the labor force. As can be seen from the figure, the majority of women do not take place in employment due to their responsibilities as housewives. This is quite related to marriage and be a mother (İlkkaracan,2012: 17-20). ${ }^{3}$

\footnotetext{
${ }^{3}$ For more information about the effects of marriage to the labor force participation of women see, İlkkaracan, (2012)
} 


\section{Figure -1: Reasons of not being in Labor Force (\%)}

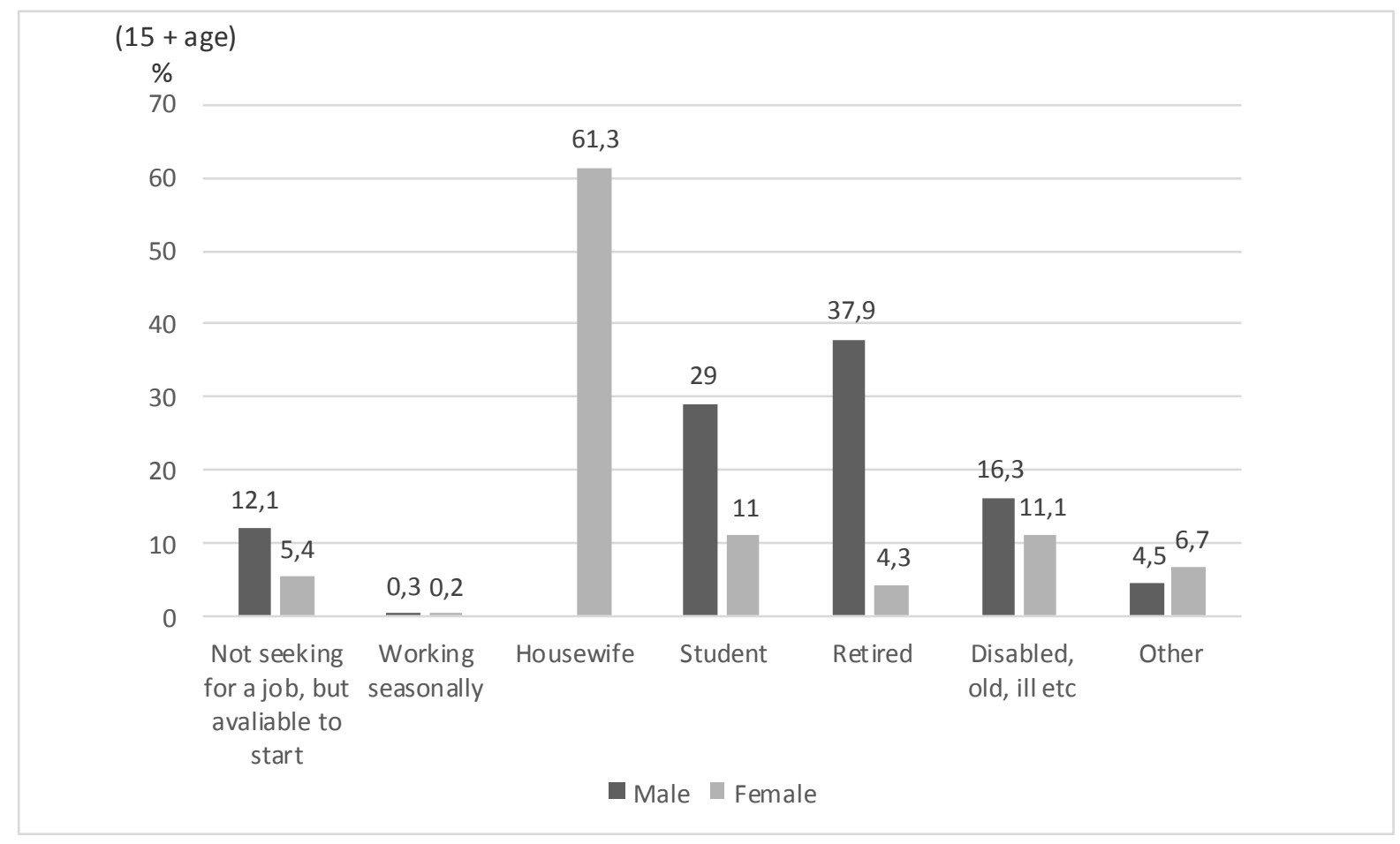

Source: (Turkstat, 2012:72)

As a biological feature, maternity appears as a factor excluding women from working life in accordance with the conservative characteristic of the labor market. After giving birth and being kept away from working life, employers become less eager to employ women because of the informal working relations. The position of women being kept away from the labor market due to the maternity is not only the consequence of giving birth but also emerges after giving birth and during parenting. Because of the patriarchal relations within the family, women substantially bear the parenting responsibility and this leads to a grave impediment for women being consistent in working life. Women are either completely kept in indoors or are not favored by employers that consider child caring services inside the work place as an extra cost. Thus, the growing conservative aspect suggesting women, who are also mothers, should be kept away from working life and the economic worries due to the maternity during and after the whole period determine the position of women and result in the exclusion of women from the labor market.

The gender-based division of labor in Turkey mostly enforces women to carry out the housework, child and elder care. The total work load of women is always higher than men no matter which category the women stands (Memiş et al. 2012: 178). Among the OECD and thirty non-OECD countries between the female population aged 15-64 Turkey has the highest proportion of the time spent in household maintenance. Nevertheless, compared with the EU countries the difference of time spent for household maintenance between men and women is four times higher in Turkey. Although women manage to take place in employment and operate in income bringing activities, the inequality in the intra-household division of labor still retains its structure. Therefore, in income poor households the gap 
between men and women widens and men and women's share of the increased workload is distributed against women (KEIG, 2013: 16-17). Eventually, women frequently get excluded from the labor market and give up on searching for a job. As a result of gender discrimination based on gender-based division of labor, the labor demand for women decreases and the wages of women who are already in the labor market fall.

In connection with the conservatism, another reason which excludes women from the labor market is patriarchal relations in working life. Patriarchy affects women in working life within the scope of patriarchal working relations. The numerous surveys conducted in Turkey concerning the position of women employment point out that women face with many serious obstacles when entering into the labor market and during the whole employment period because of the patriarchal relations. In respect to this, how conservatism and patriarchy negatively affects women in working life can be explained by different patterns of male behaviors. One of the most common patterns of behavior is the humiliation of men in the society who let their wives work. However, poverty is a significant fact in the decision of female employment. So women employment increases when the wages of men fall or when men become unemployed and the idea of "if women work, the reason is poverty" is a real fact within the Turkish society. On the other hand, when men's economic condition improves the participation of women in the labor market decreases.

Sexual abuse and humiliation of female work are also very common in the employment relations. In a society which is not accustomed to the togetherness of men and women the idea of working together brings about some social problems because of the conservative and patriarchal culture. Consequently the male employers refuse to hire female workers and as a result of this perception a vicious cycle which hinders female employment is created (Buğra , 2010: $11-14$ ). ${ }^{4}$

\footnotetext{
${ }^{4}$ For detailed information see Buğra, (2010).
}

Although the conservative and patriarchal patterns of behavior relatively diminish with the increase of education, even educated women can face with various forms of discrimination in working life. Especially while entering into a job, women confront difficulties determined by the patriarchal culture values and the gender roles created by these values. This has a great influence on the determination of the forms of female employment and the jobs "fit" for women (Toksöz, 2006: 2).

In some urban areas, women participation in the labor market is hindered severely within the framework of patriarchy and in some other urban areas women participation in the labor market is favored only when they perform particular jobs such as being teachers, attorneys, civil servants etc. (Buğra, 2010: 11). Women participation in the labor market is also favored when poverty rate increases. When men get low wages, it becomes incentive for women participation in working life. Nevertheless, this incentive situation never becomes overwhelming in terms of patriarchal working relations and women are obliged to perform indoor activities or are not employed in paid jobs. The conservatism and the paternalism in the employment relations exclude women from the labor market since the women employment endangers the traditional perception of men being the head of the household. Therefore the employment decision and the determination of suitable jobs for women are dependent on men and domestic responsibilities fulfilled. Women who somehow do the housework and fulfill care responsibilities or get formal/informal care services are able to remain more and longer in the working life. This fact shows how important the supportive services of care responsibilities are for women to participate in the labor market.

However, in Turkey care responsibilities are transferred to other women because of the insufficiency of institutional care services and the fact that the social protection benefited by an important number of people is 
dependent on the family. This applies to both child care and elder care. In households where the level of income is relatively low the care services are transferred to other women of the family; whereas in households where the level of income is higher illegal women immigrants are employed (Gökbayrak, 2009). The households which have higher levels of income also have the opportunity to buy care services from the market. However, in every case the care responsibility is still carried by women and this in one hand excludes women from the labor market and formal services of the welfare state; on the other hand makes women the invisible workers of the welfare state. This structure is supported by the tendency of getting conservative which recently comes into prominence more. Women take advantage from social benefits in exchange for care services conducted by women to their relatives residing at homes; yet at this point women become dependent on the social security system. Nevertheless, women who are somehow able to gain access to the social security system are still exposed to different forms of discrimination due to the gender based structure of the social security system.

\section{III- The Status of Women in the Turkish Social Security System}

The Turkish Social Security System basically provides social protection only those who take place in regular/formal employment. As the labor force participation rate for women is quite low in Turkey, the social security system is biased towards men. Therefore the status of women in the Turkish Social Security system can be explained by two points of view: Firstly, from the point of educated women who generally take place in urban formal labor market and secondly the uneducated women who are either unemployed or take place in the urban or rural informal sector such as housework, child and elder care. The first group constitutes a quite low proportion within the total amount. The majority of this group especially works as civil servants or workers in the public sector which is considered traditionally a female sector. With the privatization of public enterprises, the implementations of flexible working and unsecured employment in the public sector over the recent years either exclude women from the social security system by making them become unemployed or create difficulties in ensuring conditions required by the social security system. The subcontracting implementations in the private sector potentially exclude women from the social security system, as well. Beside these structural conditions, as mentioned above, even the educated women can face difficulties while entering to a job, holding on to a job or make progress in the job. As a result of the genderbased division of labor, women are mostly expelled from the labor market and they are not able to fulfill the number of premium payment days and the other conditions required by the social security system for pension and other benefits(Gökbayrak, 2011).

In the second group, uneducated women face with more serious challenges concerning the social protection. Because of the unsecure and informal employment structure in Turkey, women are not able to fulfill the contribution that required by the social security system. According to İlkkaracan, "three quarters of women are nonparticipant, and half of the 
participants are unregistered, a majority of women are excluded by definition from direct access to the social security system. They have only indirect access as dependents in their status as wives, daughters, or mothers" (2012: 15). Thus, housewives and women employed in informal sector are forced to be dependent on their husbands and fathers in terms of the social security. Table -4 illustrates the appearance of social exclusion and dependency of women in Turkey.

Table - 4: The Dependent and Excluded Women in Turkey

\begin{tabular}{|l|l|l|l|}
\hline & \multicolumn{1}{|c|}{ Wife } & \multicolumn{1}{c|}{ Girl Child* } & \multicolumn{1}{c|}{ Mother } \\
\hline Dependent & $\begin{array}{l}\text { Women whose } \\
\text { husbands work in an } \\
\text { insured job }\end{array}$ & $\begin{array}{l}\text { Women whose mothers or } \\
\text { fathers work in an insured } \\
\text { job }\end{array}$ & $\begin{array}{l}\text { Women whose daughters or sons } \\
\text { work in an insured job }\end{array}$ \\
\hline Excluded & $\begin{array}{l}\text { Women whose } \\
\text { husbands do not work } \\
\text { in an insured job }\end{array}$ & $\begin{array}{l}\text { Women whose mothers or } \\
\text { fathers do not work in an } \\
\text { insured job }\end{array}$ & $\begin{array}{l}\text { Women whose daughters or sons } \\
\text { do not work in an insured job }\end{array}$ \\
\hline $\begin{array}{l}\text { Dependent } \\
\text { Beneficiary) }\end{array}$ & $\begin{array}{l}\text { Women whose insured } \\
\text { husbands are dead }\end{array}$ & $\begin{array}{l}\text { Women whose insured } \\
\text { fathers or mothers are dead }\end{array}$ & $\begin{array}{l}\text { Women whose insured daughters } \\
\text { or sons are dead }\end{array}$ \\
\hline Excluded & $\begin{array}{l}\text { Women whose } \\
\text { uninsured husbands } \\
\text { are dead }\end{array}$ & $\begin{array}{l}\text { Women whose uninsured } \\
\text { fathers or mothers are dead }\end{array}$ & $\begin{array}{l}\text { Women whose uninsured } \\
\text { daughters or sons are dead }\end{array}$ \\
\hline
\end{tabular}

Source: (KEİG, 2008: 18)

*Unmarried women above 18 and do not take place in regular employment

Table - 5: Gender-Based Distribution of Compulsory Insured Persons Within the scope of Social Security in $2012^{*}$

\begin{tabular}{|c|c|c|c|c|c|c|c|c|c|c|c|c|}
\hline \multirow{2}{*}{\multicolumn{3}{|c|}{$\begin{array}{c}\text { Compulsory insured persons } \\
\text { under article 4-1/a of act } 5510 \\
\text { (Paid workers) }\end{array}$}} & \multicolumn{6}{|c|}{ Compulsory insured persons under article $4-1 / b$ of act 5510} & \multirow{2}{*}{\multicolumn{3}{|c|}{$\begin{array}{c}\text { Active insured persons } \\
\text { under article } 4-1 / c \text { of act } \\
5510 \\
\text { (Civil servants) }\end{array}$}} & \multirow[b]{2}{*}{ Total } \\
\hline & & & \multicolumn{3}{|c|}{ Self employed by the act of 1479} & \multicolumn{3}{|c|}{$\begin{array}{l}\text { Self employed by the act of } \\
2926\end{array}$} & & & & \\
\hline Female & Male & Total & Female & Male & Total & Female & Male & Total & Female & Male & Total & 17.558.133 \\
\hline $\begin{array}{c}2.981 .779 \\
(16.9 \%)\end{array}$ & $\begin{array}{l}8.957 .841 \\
(51 \%)\end{array}$ & $\begin{array}{c}11.939 .620 \\
(68 \%)\end{array}$ & $\begin{array}{c}391.219 \\
(2.2 \%)\end{array}$ & $\begin{array}{c}1.507 .834 \\
(8.5 \%)\end{array}$ & $\begin{array}{c}1.899 .053 \\
(10.8 \%)\end{array}$ & $\begin{array}{c}153.912 \\
(0.8 \%)\end{array}$ & $\begin{array}{c}902.940 \\
(5,1 \%)\end{array}$ & $\begin{array}{c}1.056 .852 \\
(6 \%)\end{array}$ & $\begin{array}{c}877.889 \\
(4.9 \%)\end{array}$ & $\begin{array}{c}1.784 .719 \\
(10.1 \%)\end{array}$ & $\begin{array}{c}2.662 .608 \\
(15.1 \%)\end{array}$ & $(100 \%)$ \\
\hline
\end{tabular}

Source: Generated from SSI, Statistical Yearbook, 2012

*Figures in table may not add up to totals due to rounding.

\footnotetext{
${ }^{5}$ http://www.keig.org/content/raporlar/SSGSS 10mart2008 web.pdf (13.07.2013)
} 
Table - 6: The Insurance Status of Persons Who Receive Pension Benefits and The Gender Based Distribution in 2012*

\begin{tabular}{|c|c|c|c|c|c|}
\hline $\begin{array}{c}\text { Insurance } \\
\text { Status }\end{array}$ & $\begin{array}{c}4-\mathrm{a} \\
\text { (Paid workers) }\end{array}$ & $\begin{array}{c}4-\mathrm{b} \\
\text { (Self-employed) }\end{array}$ & $\begin{array}{c}4-\mathrm{b} \\
\text { (Self-employed in } \\
\text { agriculture) }\end{array}$ & $\begin{array}{c}4 \text {-c } \\
\text { (Civil servants) }\end{array}$ & Total \\
\hline Women & 824.358 & 195.296 & 14.604 & 371.836 & 1.406 .094 \\
& $(12 \%)$ & $(3 \%)$ & $(0.2 \%)$ & $(5.2 \%)$ & $(19.8 \%)$ \\
\hline Men & 3.411 .138 & 961.803 & 382.027 & 904.819 & 5.659 .787 \\
& $(48 \%)$ & $(14 \%)$ & $(5.4 \%)$ & $(13 \%)$ & $(80.2 \%)$ \\
\hline Total & 4.235 .496 & 1.157 .099 & 396.631 & 1.276 .655 & 7.065 .881 \\
& $(60 \%)$ & $(16 \%)$ & $(5.6 \%)$ & $(18 \%)$ & $(\mathbf{1 0 0} \%)$ \\
\hline
\end{tabular}

Source: Generated from SSI, Statistical Yearbook, 2012

*Figures in table may not add up to totals due to rounding.

As can be seen from Table - 4 very few women directly participate in the Turkish Social Security System and the rest is either dependent on men or excluded from social protection. As a result of the exceeding numbers of the unregistered/ informal employment, the social security system is not able to include women. At the same time due to the lower wages and temporary/precarious employment status of women, being included in the private pension system is getting harder. Even if women take place in the private pension system, their pensions are substantially low. Exclusion from the social security system leads women to become dependent on social care when they get older. It is a significant contradiction for women to carry out all types of social care when they are economically active but become dependent on social care for themselves during old age.

After the marketization/privatization of the social security system in Turkey, the regulations prescribed an increase in the number of premium payment days and the retirement age have increased the social exclusion of women as a result.

The Table -5 ones more, illustrates the emphasis of the relation between the women's access of social security and the working practices. As can be seen clearly in the table above by the year 2012 the ratio of compulsory insured women is significantly low when compared with compulsory insured men. When the situation of insured women according to different employment status is analyzed, the women working in agriculture are regarded as the most problematical group. As mentioned above, although the portion of agriculture sector has been narrowed in the total employment ratio, the agriculture sector still remains its importance in terms of women employment.

Whereas women employed in agriculture mostly as unpaid family workers are entirely excluded from compulsory insurance; the number of self-employed women is barely 153.912. It is also problematic whether insured women working in agriculture fulfill their insurance liabilities periodically. The problems in agriculture sector regarding the level and continuity of income prevent agricultural workers from participating to the system and this mostly affects women.

When the Table-5 is evaluated in terms of self-employed women working in nonagricultural sectors, the scarcity of selfemployed women in the labor market causes the fact that the number of those insured women is significantly lower than the number of self-employed men. 
Although the biggest proportion of compulsory insured women consists of those who work in the form of dependent employment as paid workers; it is a fact that the number of insured women workers is significantly low amongst all paid women workers especially when considering the ratio of women amongst workers employed in urban areas in the form of unregistered employment. It is also seen that when the status of paid women workers and the working practices in the labor market are considered, the paid women workers meet with some obstacles in terms of participating to the system even though they are somehow insured.

As can also be seen in Table- 5 that the number of women amongst the active insured persons working under article 4-c in public sector as civil servants is low considering that the traditional area of women employment is public sector. Even though the absence of similar data concerning the insured persons under article 4-c in the previous statistical yearbooks of SSI enables an accurate evaluation regarding the said development trend; it is assumed that the decrease of employment in public sector and the dissemination of unsecured employment produce an effect in the direction of a decrease in the number of insured women workers employed in public sector.

The gender inequality among active insured workers in working period also passes through the retirement period. As can be seen in Table-6, in 2012 the number of women amongst the passive insured persons receiving pension benefits is significantly lower than the number of men. Another aspect is that the gender-based differences between the active insured workers according to working forms are also applicable to passive insured persons. This table is remarkable because it indicates that gender inequalities emerging according to the working status in the labor market pass through the retirement period. Therefore, eliminating the gender-based stratification in the labor market emerging according to the working status increases not only the welfare of currently working women but also the welfare of old women.

Table - 7: The Gender-Based Distribution of Dependent Insured Persons

\begin{tabular}{|c|c|c|c|c|c|c|c|}
\hline \multirow[t]{2}{*}{ Insurance Status } & \multicolumn{6}{|c|}{$\begin{array}{l}\text { Dependent Insured Persons Receiving Benefits in Terms of Types of Long Term } \\
\text { Insurance (Old-Age, Invalidity, Death Insurances)* }\end{array}$} & \multirow[t]{2}{*}{ Total } \\
\hline & Wife & Husband & Daughter & Son & Mother & Father & \\
\hline $\begin{array}{l}\text { 4-a } \\
\text { (Paid Workers) }\end{array}$ & $\begin{array}{l}1.004 .959 \\
(31.5 \%)\end{array}$ & $\begin{array}{r}22.604 \\
(0.7 \%)\end{array}$ & $\begin{array}{l}430.153 \\
(13.5 \%)\end{array}$ & $\begin{array}{l}112.435 \\
(3.5 \%)\end{array}$ & $\begin{array}{l}10.314 \\
(0.3 \%)\end{array}$ & $\begin{array}{c}1.936 \\
(0.06 \%)\end{array}$ & $\begin{array}{c}1.582 .401 \\
(49.7 \%)\end{array}$ \\
\hline $\begin{array}{l}\text { 4-b } \\
\text { (Self-employed) }\end{array}$ & $\begin{array}{c}446.584 \\
(14 \%)\end{array}$ & $\begin{array}{l}9.364 \\
(0.3 \%)\end{array}$ & $\begin{array}{l}205.186 \\
(6.4 \%)\end{array}$ & $\begin{array}{l}49.135 \\
(1.5 \%)\end{array}$ & $\begin{array}{c}2.775 \\
(0.08 \%)\end{array}$ & $\begin{array}{c}484 \\
(0.01 \%)\end{array}$ & $\begin{array}{l}713.528 \\
(22.2 \%)\end{array}$ \\
\hline $\begin{array}{l}\text { 4-b(Self-employed in } \\
\text { agriculture) }\end{array}$ & $\begin{array}{c}126.224 \\
(3.9 \%)\end{array}$ & $\begin{array}{c}502 \\
(0.01 \%)\end{array}$ & $\begin{array}{l}40.628 \\
(1.2 \%)\end{array}$ & $\begin{array}{c}126.224 \\
(4 \%)\end{array}$ & $\begin{array}{c}591 \\
(0.01 \%)\end{array}$ & $\begin{array}{c}176 \\
(0.005 \%)\end{array}$ & $\begin{array}{c}294.345 \\
(9.2 \%)\end{array}$ \\
\hline $4-c^{* *}$ & $\begin{array}{l}311.918 \\
(9.8 \%)\end{array}$ & $\begin{array}{l}8.565 \\
(0.2 \%)\end{array}$ & $\begin{array}{l}220.302 \\
(6.9 \%)\end{array}$ & $\begin{array}{c}31.104 \\
(1 \%)\end{array}$ & $\begin{array}{l}12.761 \\
(0.4 \%)\end{array}$ & $\begin{array}{l}7.471 \\
(0.2 \%)\end{array}$ & $\begin{array}{l}592.121 \\
(18.2 \%)\end{array}$ \\
\hline Total & $\begin{array}{c}1.889 .685 \\
(59.3 \%)\end{array}$ & $\begin{array}{l}41.035 \\
(1.2 \%)\end{array}$ & $\begin{array}{l}896.269 \\
(28.1 \%)\end{array}$ & $\begin{array}{c}318.898 \\
(10 \%)\end{array}$ & $\begin{array}{l}26.441 \\
(0.8 \%)\end{array}$ & $\begin{array}{l}10.067 \\
(0.3 \%)\end{array}$ & $\begin{array}{c}3.182 .395 \\
(100 \%)\end{array}$ \\
\hline
\end{tabular}

Source: Generated from SSI, Statistical Yearbook, 2012

*Figures in table may not add up to totals due to rounding.

**4-c consists of dependent insured persons receiving benefits in terms of disability, occupational disability, old age and military service. 
The disadvantaged status of women as a result of gender-based division of labor in the labor market cause their dependency on men in terms of gaining access to the social security. As can be seen in Table -7 the number of dependent insured women receiving benefits within the scope of types of long term insurance is significantly high when comparing with men. This is important because it shows that the social security of women is considerably dependent on their husbands, father or sons. The dependent status of women on men in labor market in terms of gender-based division of labor also causes dependency in the social security system. The participation of women into the labor market and keeping them in it permanently are necessary to eliminate the dependency considering the characteristics of the social security system. It is not enough only to make women visible in the labor market. It is also required that women need to be concentrated on secure and permanent jobs to enable them move upwards in labor markets.

According to the data of SSI in 2012, the number of active insured persons who contribute to the social security system is 18.352.859; whereas the number of passive insured persons (who get monthly salaries) is 9.635.709 and the number of dependent insured workers is 33.807.725. The gender inequalities in work life cause women's active/passive insurance status to include lower rights when compared with men (Şahin, 2012: 234). When women become more active in labor markets, it causes a decrease on the number of dependent workers that put a pressure on the balance of income-spending in the social security system and thus improve the actuarial balances of the system because the significant portion of the dependent insured persons consists of women. 


\section{Conclusion}

In Turkey the social security system is based on the Bismarckian model that provides protection upon work and this makes the access into the social security system primarily dependent on taking place in the labor market. Thus, gaining access to the social security system and the benefits of the system are closely associated with being in the labor market, the working status, the period and the amount of contributions to the system. In this respect, the Turkish welfare system shows the characteristics of the conservative/corporative welfare system. However, the segmented structure of the labor market in Turkey constitutes a very complicated structure in terms of gaining access to the social security system and its benefits.

The labor market in Turkey differs significantly from formal to informal sector and rural to urban areas and this also leads to a differentiation in the social inclusion implementations. This segmented structure of the labor market also creates a sophisticated frame in accessing and benefiting from the social security system. This fact causes Turkish welfare system to be parted from the conservative/corporatist form. Considering this segmented structure, the welfare system in Turkey shows a great resemblance to the Southern European welfare systems. In terms of gaining access to the social security and enjoying the rights, this structure affects mostly women on gaining access into the labor market and being permanent in it because of the gender roles.

Gender roles and conservatism that consistently provokes to reproduce these roles prevent women from gaining access to the labor market and/or shorten the period of being in the labor market or generate irregular and atypical forms of labor. The disadvantages of women in the labor market do not only affect their current income and security, they also affect their access to the social protection in which the working practices are decisive and on their future security. For many women the social inclusion is realized either by being dependent on their husbands or fathers. If women do not have the opportunity to enter into the system upon men, they become dependents on social assistance. Yet, many women contribute to the creation of welfare as invisible workers of the welfare state within the scope of reproduction of the labor and care proceeding because of the gender roles. Although women contribute to the creation of welfare by being in a secondary status in the labor market, they are still excluded from the value which they create.

The exclusion of women in Turkey as a result of their status in the labor market reproduces itself consistently and this causes a vicious circle which leads to an intertemporal transfer. By breaking this vicious circle, some policies and practices which help to increase women employment both qualitatively and quantitatively are primarily required. In this respect, firstly employmentfriendly macro-economic policies and gender-friendly employment policies should be implemented. Besides, the public social security system should be protected and this system should be operated more efficiently. Moreover, gender equality and antidiscrimination policies in the social security system and the labor market are needed to be improved. Effective and higher quality social care services should be provided by the state by promoting institutional child and elder care such as nurseries for children and resting homes for the aged. These implementations, policies and practices are vital to enable the social inclusion of women and to break the vicious circle emerged in the labor market which affects the social security system that transfers the inequalities throughout the time. 


\section{References}

Buğra A. and Keyder Ç.(2003), New Poverty and the Changing Welfare Regime of Turkey, UNDP, Ankara.

Buğra A.(2010) Toplumsal Cinsiyet, Işgücü Piyasaları ve Refah Rejimleri: Türkiye'de Kadın İstihdamı, TÜBİTAK Project: İstanbul.

Bussemaker, J. and Kersbergen, K. (1994), “Gender and the Welfare state: Some Theoretical Reflections", in D. Sainsbury (ed.), Gendering Welfare States, Sage Publications: London

Ceylan Ataman, B. (1999) İşgücü Piyasası ve İstihdam Politikasinin Temel Prensipleri, Ankara Üniversitesi Siyasal Bilgiler Fakültesi İstihdam ve Danışmanlık Hizmetleri Eğitim Programı, Ankara.

Dayığlu, M. and Kırdar, M.G. (2010) “Türkiye'de Kadınların İşgücüne Katılımında Belirleyici Etkenler ve Eğilimler", DPT and Worldbank, Welfare and Social Policy Analytical and Advisory Work, Working Report, No:5, Ankara,

[http://siteresources.worldbank.org/INTT URKEYINTURKISH/1472541269017398324/22612354/KadinlarinIsgucu neKatilimi.pdf] (25.07.2013)

Dedeoğlu, S. (2000) “Toplumsal Cinsiyet Rolleri Açısından Türkiye'de Aile ve Kadın Emeği", Toplum ve Bilim, No: 8,:139-170.

Dedeoğlu, S. (2009) “Eşitlik mi Ayrımcılık mi? Türkiye'de Sosyal Devlet, Cinsiyet Eşitliğ Politikaları ve Kadın İstihdamı", Çalışma ve Toplum Dergisi, 2 :41-54.

Delsen, L. N. van Gestel and F. Pennings (2000) Introduction: Changes in European Social Security. In: J. van Vugt et al. (Ed) Social Security and Solidarity in the European Union. Facts, Evaluations and Perspectives, Heidelberg: Physica Verlag.

Ecevit, Y. (2009) “Türkiye'de Üç Kentte Kadın İstihdamını Artırıcı Çalışmalar İçin Ön Adımlar ve Tavsiyeler Raporu" Türkiye'de Kadınlar için Insana yakışır İş Imkânları Sağlanması Yoluyla Toplumsal Cinsiyet Eşitliğinin Gerçekleştirilmesine Yönelik Aktif
İşücü Piyasası Politikaları ILO ve İŞKUR Pilot Projesi, ILO Ankara. [http://www.ilo.org/public/turkish/region/ eurpro/ankara/areas/woman/3 rapor/kadi $\underline{\mathrm{n} \text { istihdami_artirici_calismalar.pdf] }}$ (13.07.2013)

Erdut, T. (2005) "İşgücü Piyasasında Enformelleşme ve Kadın İşgücü", Çalışma ve Toplum Dergisi, 3: 11 - 49 .

Esping - Andersen, G. (1990) The Three Worlds of Welfare Capitalism, Cambiridge: Policy Press.

EUROSTAT (2012) “Labour Market and Labour Force Statistics: European Union Labour Force Survey - Annual Results 2012" [http://epp.eurostat.ec.europa.eu/statistics explained/images/6/6d/Employed perso ns economic activity \%2C 2012.png] (12.07.2013)

Ferrera, M. (1996), "The Southern Model of Welfare in Social Europe", Journal of European Social Policy, 6(1): 17-37.

Gökbayrak Ş. (2009), "Refah Devletinin Dönüşümü ve Bakım Hizmetlerinin Görünmez Emekçileri Göçmen Kadınlar", Çalışma ve Toplum, 21(2): 55-82.

Gökbayrak, Ş. (2011), “İşgücü Piyasaları ve Sosyal Güvenlikte Dönüşüm Ekseninde Kadınların Emeklilik Güvencesi", Çalışma ve Toplum, 29(2): 165-190.

Günsoy, G. and Özsoy C. (2012). “Türkiye'de Kadın İşgücü, Eğitim ve Büyüme İlişkisinin Var Analizi" Finans Politik ve Ekonomik Yorumlar Dergisi, No: 568, Year:49, June:2342.

ILO, (2012). “Global Employment Trends 2012: Preventing a Deeper Jobs Crisis, International Labour Office, Geneva [http://www.ilo.org/wcmsp5/groups/publi c/@dgreports/@dcomm/@publ/documents/ publication/wcms 171571.pdf (28.05.2013)

Kalaycıoğlu, S. \& Rittersberger-Tılıç, H. (1998). „"IIş İlişkilerine Kadınca Bir Bakış: Ev Hizmetinde Çalışan Kadınlar. A. Berktay Hacımirzaoğlu (Der.), in 75 Yilda Kadınlar 
ve Erkekler. Tarih Vakfı Bilânço Dizisi,

Tarih Vakfı Yayınları: İstanbul: 225-235.

KEIGG (2013) “Türkiye'de Kadın Emeği ve İstihdamı: Sorun Alanları ve Politika Önerileri II" KEİG Platformu, İstanbul. [http://www.keig.org/content/raporlar/içer ik.pdf] (14.11.2013).

Memiş, E., Öneş, U. ve Kızılırmak, B. (2012) "Kadınların Ev-Kadınlaştırılması: Ücretli ve Karşılıksız Emeğin Toplumsal Cinsiyet Temelli Bir Analizi" S. Dedeoğlu, A. Y. Elveren (eds.) Türkiye'de Refah Devleti ve Kadın. İletişim Publucations, Istanbul

Sapancalı, F. (2008) “Türkiye'de İşgücü Piyasası, Sorunlar ve Politikalar" TüHİS İş Hukuku ve Iktisat Dergisi, 21(2): 8-30.

SSI, (2013) “Turkey's Statistical Yearbook 2012" Turkish Statistical Institute, Ankara.

Şahin, M. (2012) “Türkiye'de Sosyal Güvenlik Reformu ve Kadınlar Üzerine Etkisi" in. S. Dedeoğlu, A. Y. Elveren (eds.) Türkiye'de Refah Devleti ve Kadın. İletişim Publucations, Istanbul

Özar, Ş. and B.Yakut-Çakar, (2012) “Aile, Devlet ve Piyasa Kıskacında Boşanmış Kadınlar", Kültür ve. Siyasette Feminist Yaklaşımlar, Vol. 16.SAYFA NO

Özdemir, S. (2005) “Refah Devletinin Gelişme ve Bunalım Dönemlerinde İş Piyasaları", Iktisat Fakültesi Mecmuası, (Prof. Dr. Toker Dereliye Armağan Özel Sayısı), 55(1): 695-733.

Özkaplan, N. (2008) “Türkiye İşgücü Piyasasının Dönüşümü(1980-2007)”, Gülen Elmas Aslan(ed.), in Cumhuriyetin 85. yılinda Türkiye Ekonomisi, Gazi Üniversitesi Publications, October.

Toksöz, G. (2007). Women's Employment Situation in Turkey, International Labor Office (ILO), Ankara

Toksöz, G. (2012) “Kalkınmada Farklı YörüngelerKadın İstihdamında. Farklı Örüntüler Işı̆̆ında Türkiye'de Kadın İstihdamı" in Geçmişten Günümüze Türkiye'de Kadın Emeği, Gülay Toksöz ve Ahmet Makal (eds), Ankara Üniversitesi Yayınları:168 200
TURKSTAT, (2012) "İstatistiklerle Kadın - Women in Statistics 2012" Turkish Statistical Institute, Ankara

TURKSTAT, (2013) “Household Labor Force Survey Results" Vol: 13549, Ankara

[http://www.tuik.gov.tr/PreHaberBultenle ri.do?id=13549] (19.07.2013) 
The Effects Of Gender Inequalities In The Labor Market And The Social Security System On Women's Social Inclusion In Turkey, Osman TEZGEL, Şenay GÖKBAYRAK 